\title{
Cultura e cotidiano nas minas de ouro: trabalhadores em tempos de experiências autoritárias e suas resistências plurais
}

\author{
Andréa Casa Nova Maia
}

\section{Introdução}

\begin{abstract}
Espero que a cultura plebeia tenha se tornado um conceito mais concreto e utilizável, não mais situado no ambiente dos "significados, atitudes, valores", mas localizado dentro de um equilíbrio particular de relaçôes sociais, um ambiente de trabalho, exploração e resistência à exploração, de relaçôes de poder mascaradas pelos ritos do paternalismo e da deferência. Desse modo, assim espero, a "cultura popular" é situada no lugar material que lhe corresponde.

E. P. Thompson, Costumes em comum, 1998.
\end{abstract}

O objetivo deste artigo é responder, ainda que parcialmente, em primeiro lugar, quais eram as estratégias dos trabalhadores da mina de Morro Velho, em Nova Lima, Minas Gerais, nas décadas de 1930 e 1940, frente à ação da propaganda getulista. Analisarei brevemente o rádio e sua repercussão na vida cotidiana dos mineiros, como também, em segundo lugar, estudarei outras "artes de fazer" dos operários. Discutirei como, face ao controle inglês (a mina era de propriedade de ingleses), os sujeitos - no caso, um dos "contadores de história" que entrevistei para esta pesquisa, o senhor Waldir dos Santos, artista anônimo, sambista, boêmio e carnavalesco - aprenderam a "se virar" no dia a dia. Não quero transformá-los em filósofos, mas sim, como afirma Robert Darnton, "ver como a vida comum exigia uma estratégia. Operando no nível corriqueiro, as pessoas comuns aprendem a 'se virar' - e podem ser tão inteligentes, à sua maneira, quanto os filósofos". ${ }^{1}$

O rádio no tempo de Getúlio Vargas: mero reprodutor de ideias autoritárias?

O mundo atravessa uma fase dramática de reconstituição. Velhos preceitos, antigas doutrinas, normas até bem pouco tempo pacíficas, sofrem os influxos da guerra, que contaminou todos os povos. Não sabemos com segurança o que nos aguarda e devemos estar vigilantes. O rádio, cada manhã, pela rapidez da palavra, será sempre agente eficaz dos propósitos que nos animam e das cautelas que as contingências nos impõem. ${ }^{2}$

A problemática da simultaneidade entre controle e antidisciplina é talvez a grande dificuldade teórica e histórica de se pensar o cotidiano dos trabalhadores da mina de Morro Velho, em sua relação com seus patróes ingleses e com o Estado getulista. Afinal, por um lado, remete-se à ideia de controle, ainda que, por outro lado, se reconheça todas as ambiguidades dela recorrentes. Atribuir aos trabalhadores um papel ativo significa reconhecer um diálogo entre sujeitos com poderes diferenciados, mas igualmente capazes de se apropriar e reler as propostas político-ideológicas um do outro. Tal postura, adotada na presente discussão, tem como objetivo afastar a dicotomia entre autonomia e heteronomia.

A construção da imagem mítica de Getúlio Vargas está associada, principalmente, ao longo tempo em que ele permaneceu no poder, além de realizações materiais e simbólicas que efetivamente aconteceram na vida dos trabalhadores. Assim, é importante observar que durante o Estado Novo uma série de mecanismos de difusão da ideologia getulista foram criados. Até que ponto a ideologia é difundida pelo rádio? Como era a difusão radiofônica em Nova Lima? Os mineiros ouviam rádio? É relevante, portanto, discutir o papel do rádio como difusor das ideias de Vargas e seu grupo de intelectuais, colocadas em prática por meio do DIP, da Rádio Nacional, da "Hora do Brasil”, da Rádio Inconfidência, bem como de outros meios de comunicação. É registro comum na historiografia do período que foi neces- 
sário para o Estado varguista a construção de mecanismos de difusão de uma doutrina própria, sendo o rádio um dos principais meios através dos quais o Estado buscou o apoio dos trabalhadores, "o povo brasileiro". Analisar tal meio de comunicação torna-se importante na tentativa de compreender até que ponto o "mito" Vargas não foi construído puramente através da vasta propaganda doutrinária veiculada pelo DIP. Afinal, concorda-se aqui com Jorge Ferreira em sua afirmação de que:

Não há propaganda, por mais elaborada, sofisticada e massificante, que sustente uma personalidade pública por tantas décadas sem realizações que beneficiem, em termos materiais e simbólicos, o cotidiano da sociedade. O "mito" Vargas, assim, exprimia um conjunto de experiências que, longe de se basear em promessas irrealizáveis, fundamentadas tão-somente em imagens e discursos vazios, alterou a vida dos trabalhadores. ${ }^{3}$

Ao observar no Brasil os períodos autoritários que correspondem ao Estado Novo e à ditadura militar pós-1964, nota-se como o conteúdo das mensagens radiofônicas se altera nos momentos de controle estrito do Estado. No caso brasileiro, a lógica com que o Estado opera ao controlar o conteúdo dos meios de comunicação é restritiva. O poder do Estado sobre a radiodifusão sempre foi grande. Parece que o Estado e os grupos privados não expressam interesses fundamentalmente distintos. Desse modo, não se deve esperar que as mensagens sob controle de um ou de outro apresentem grandes diferenças ideológicas.

A radiodifusão teve início mais precisamente em 6 de abril de 1919, quando, com um transmissor importado da França, foi inaugurada a Rádio Clube de Pernambuco, por Oscar Moreira Pinto, que, depois, se associou a Augusto Pereira e João Cardoso Ayres. Mas, oficialmente, pode-se considerar o início da radiodifusão no Brasil com a instalação da primeira emissora de rádio, em 20 de maio de 1923 (Rádio Roquette Pinto), embora, naquele momento, nem o Estado, nem os proprietários privados se interessavam tanto pelo serviço. A Rádio Sociedade do Rio de Janeiro foi fundada por Henrique Morize e Edgard Roquette Pinto. Somente em 11 de junho de 1927, depois de um período de experiência, é que começou a funcionar, no Rio de Janeiro, a Rádio Mayrink Veiga. Os donos das primeiras emissoras eram intelectuais e cientistas imbuídos de intenções, pelo menos a princípio, altruístas de tornar o rádio um instrumento a serviço da educação e cultura, sem finalidades lucrativas. Mas, fora esses primeiros anos de existência, a radiodifusão sempre esteve na esfera de influência do Estado e de grupos econômicos privados.

A primeira emissora brasileira foi a Rádio Roquette Pinto, como já foi dito, criada em 1923, mas somente oito anos depois, em 1931, já sob o governo de Getúlio Vargas (Governo Provisório pós-Revolução de 1930), é que apareceria o primeiro texto legal sobre radiodifusão. Foi pelo decreto 20047 que ela foi considerada de interesse nacional e de finalidade educativa. Mas até que ponto tal finalidade permaneceu presente na radiodifusão no Brasil? Que educação, que ideologia deveria ser difundida através do rádio?

O interesse do Estado pelo rádio foi aumentando, e, durante o período autoritário, no Estado Novo, criou-se o Departamento de Imprensa e Propaganda (DIP), uma unidade especializada em comunicação a serviço do governo. Era a primeira vez que o Brasil possuía um departamento desse nível, encarregado da comunicação e, por conseguinte, da difusão ideológica do Estado Novo. O DIP deveria cuidar da imagem governamental, censurar e controlar a distribuição de verbas aos meios de comunicação. É nesse período que se notará maior rigidez sobre o controle das radiodifusóes brasileiras dentro do governo getulista. Tal situação só se modificará com o fim do Estado Novo e da Segunda Guerra Mundial.

Sucintamente posso afirmar que, terminada a Segunda Guerra Mundial, o rádio se consolidou e os programas de auditório ganharam força. A Rádio Nacional, que havia sido fundada em 1936 e que seria líder de audiência por duas décadas, tornou-se, no Estado Novo, um dos maiores fenômenos de comunicação no país. Data dessa época a "coqueluche nacional", as radionovelas, e a afirmação do radiojornalismo, com o Repórter Esso. No final da década de 1950, a TV é inaugurada.

O país passa por um surto de industrialização que superará em parte o modelo agrário. Ao maior peso da publicidade vai corresponder, no plano da programação, maior ênfase no entretenimento e no trivial, em lugar da programação substantiva (cultural e educativa, ainda que elitista) dos primei- 
ros momentos. A hipótese é passível de entendimento, já que o aumento da importância comercial do rádio implicou o aumento da autonomia dos proprietários privados, em relação ao Estado. Todavia, cabe perguntar até que ponto chegava a autonomia privada, se o rádio continuava a depender da publicidade e dos favores financeiros do Estado e, sob o controle da censura, com a intervenção do DIP (desativado, apenas, após a Constituição de 1946, que garantia total liberdade de expressão, pelo menos no papel)? E até que ponto efetivou-se essa difusão ideológica, esse "controle da memória", no caso dos operários da Mina de Morro Velho? Eles ouviam rádio? Quais programas? O rádio realmente fazia parte do cotidiano desses homens, sujeitos da presente reflexão?

Antes, porém, de tentar responder a essas questôes, quero aprofundar o estudo do papel desse meio de comunicação como instrumento de divulgação ideológica do Governo Vargas, em especial, ao longo do Estado Novo.

\section{O papel do rádio na divulgação das ideias e experiências autoritárias do Estado Novo}

Ainda quando deputado, Getúlio já havia iniciado o processo de conquista da opinião dos criadores de música. Afinal, ele foi o autor do decreto legislativo 5492, de 16 de julho de 1928, que estabeleceu o pagamento de direitos autorais por todas as empresas que lidassem com músicas. A chamada Lei Getúlio Vargas foi, assim, o primeiro vínculo conhecido entre o político e a nossa música popular.

Se algum problema ocorreu para lançarem músicas pró-Getúlio antes das eleiçôes, esse problema deixou de ocorrer após a Revolução de 1930. Nas recepções que dava no Palácio da Guanabara, Getúlio convidava cantores populares, como Mário Reis e o Bando da Lua. Enquanto isso, a censura manifestava-se vigilante. Além da censura oficial, havia outra, a da Comissão de Censura da Confederação Brasileira de Radiodifusão, criada pelos proprietários de estações de rádio para proibir a transmissão de determinadas músicas que escapavam da censura oficial.

Antes mesmo do golpe de novembro de 1937, Getúlio montou um esquema de propaganda nos moldes do que fora adotado por Joseph Goebbels, na Alemanha nazista, tornando-se, provavelmente, o primeiro governante latino-americano a utilizar o rádio com fins semelhantes aos de Hitler. O próprio Getúlio parece sugerir ter adotado o modelo de Goebbels, quando em mensagem ao Congresso Nacional, em 1ำ de maio de 1937, vangloriou-se de ter elevado o número de estaçôes radiofônicas brasileiras para 42. Certamente, entre essas novas estações radiofônicas, estava a Rádio Inconfidência de Minas Gerais, criada ainda no pré-1937, precisamente em 3 de setembro de 1936. É Maria Efigênia Lage de Resende que irá explicitar melhor essa questão ao discutir o papel da Rádio Inconfidência no acordo político entre Getúlio Vargas e Benedito Valadares, que acabou por ser o interventor do Estado Novo, em Minas Gerais.

A Rádio Inconfidência, inaugurada um mês antes (3 de setembro de 1936) como rádio difusora oficial, parte integrante do evento, irradia o comício cívico, no qual discursaram, da sacada do Palácio da Liberdade, nada menos que quatorze oradores. $O$ papel da rádio como instrumento de política de massas estava efetivamente posto no governo Benedito Valadares. ${ }^{4}$

A Rádio Inconfidência acabará por se tornar um dos canais responsáveis pela difusão da ideologia estadonovista. Traçar-se-á a seguir, algumas análises a respeito do momento histórico de sua inauguração e breves considerações sobre a programação da rádio, que ilustra bem o caráter ideológico por detrás dos programas.

\section{Um exemplo mineiro: a Rádio Inconfidência}

No discurso de inauguração da Rádio Inconfidência, o governador Benedito Valadares irá conclamar a união de Minas e de todos os brasileiros em torno da figura do presidente Getúlio Vargas, proferindo palavras de ordem, tais como: "patriotismo", "trabalho", "lealdade". Também o Cardeal Dom 
Sebastião Leme discursou, chamando a atenção para a necessidade de se estar forte e coeso "para restabelecer o império da ordem, de se reaver o domínio da civilização e de reconquistar o reinado da felicidade". As falas transcritas no jornal Minas Gerais bem demonstram a postura ideológica que, a seguir, o Estado Novo tentaria impor. Foi em um jantar no restaurante da Feira de Amostras (onde, atualmente, localiza-se a Rodoviária de Belo Horizonte) que o então governador Valadares inaugurou a rádio e definiu os objetivos de implantação da mesma, no sentido de divulgar o projeto de governo estadonovista e seu ideário, ou seja, "divulgar o saber e a civilização", difundir a cultura e a educação. Os jornais da época, e mesmo posteriormente, já durante o Estado Novo, atentavam para as finalidades da estação. Veículo de divulgação e órgão educativo, a rádio deveria informar o povo. Mas quem é o povo nesse momento? O povo é "quem mais precisa de conhecimentos, conselhos, esclarecimentos e de uma orientação honesta e sincera”. Em 1942, a maioria da população mineira podia contar com o rádio como parte integrante de sua vida.

A Rádio Inconfidência cobria todo o território nacional e dispunha de uma programação diversificada que atendia aos interesses governamentais de difusão ideológica. Programas tais como "A hora da higiene", "Aula de ginástica", "Hora do universitário", "Hora escolar", "Hora do operário" e outros, além de audições cívicas em todas as grandes datas que se referiam à nacionalidade. Os ideários de construção de um homem fisicamente belo, saudável, aliado à construção de uma nação, de uma pátria, em harmonia e equilíbrio, estavam presentes na programação e nas finalidades "educativas" da Rádio Inconfidência.

A construção de um homem novo, trabalhador brasileiro, vem à tona na documentação referente às datas comemorativas do Dia do Trabalho em Belo Horizonte. A Rádio Inconfidência era a principal difusora dos discursos do presidente Getúlio Vargas e do governador Benedito Valadares. No dia 1o de maio de 1940, por exemplo, os operários, sindicalistas, diretores e associações de classe, bem como os demais elementos trabalhistas, se reuniram na Praça Rio Branco, em frente à Feira de Amostras, para ouvir o discurso de Vargas e, segundo os jornais, comemorar os benefícios concedidos à classe trabalhadora.

A Rádio Inconfidência irradiava o discurso do presidente, e os trabalhadores ouviam atentamente a retransmissão. Também durante a guerra, em 1942, Vargas falava ao povo:

A política trabalhista do meu governo tem sido invariável no sentido de estabelecer a harmonia entre os fatores da produção, base do equilíbrio social e fundamento do progresso humano. A nossa organização peculiar afasta-se igualmente do erro dos regimes de liberalismo individualista que legalizam a greve, como elemento solucionador de conflitos, e dos estatutos de natureza autoritária, que instituíram o trabalho escravo. O Estado, entre nós, exerce a função de juiz nas relaçōes entre empregados e empregadores, porque corrige excessos, evita choques e distribui equitativamente vantagens. Assiste-lhe, por isso mesmo, o direito de solicitar concurso de vossas energias, a decisão completa dos vossos esforços. Nessa emergência, deve cada homem conservar o seu porto, sem pensar em si próprio, sem pensar na família, sem pensar nos bens. Em momentos supremos, os riscos não contam, porque "é preferível perder a vida, a perder as razões de viver". ${ }^{5}$

Getúlio considerava os trabalhadores soldados que construíam a grandeza e o progresso do país. E o rádio era um dos canais de comunicação direta entre o presidente e os operários.

A Rádio Inconfidência comemorava também o aniversário do presidente, transmitindo discursos de propaganda do governo e de suas realizaçôes. ${ }^{6}$ É interessante analisar a própria programação da rádio no sentido de se entender até que ponto ela servia aos interesses ideológicos do Estado Novo. Às 7 horas da manhã, a PRI-3 já iniciava sua programação com um programa de ginástica. Os mineiros, assim como todos os brasileiros, deveriam exercitar o corpo; a nação brasileira deveria ter um corpo perfeito, de acordo com a ideologia estadonovista. Além disso, uma nação conservadora, em ordem, precisava da religião. Portanto, não poderia faltar na programação um noticiário social e religioso, além do Angelus, para todos os cristãos. Uma nação forte também deveria ter saúde, e a rádio também oferecia um programa de higiene e saúde pública.

Muita música popular para incentivar o povo a trabalhar... Agora, com a censura do DIP, as canções não falavam apenas do malandro, mas, também, do operário. Por sinal, integravam a programação, 
a "Hora do Operário" e a "Hora do Fazendeiro". Observe-se que o operário era tão valorizado quanto o fazendeiro, ambos responsáveis pela construção do Brasil, como pátria que respeitava a ordem e a paz. A cultura era o principal fator para a construção desta nação brasileira idealizada; era preciso, portanto, que o rádio também se encarregasse de auxiliar na educação, cultura e civilidade. Para tanto, a Rádio Inconfidência levava ao ar a "Hora infantil" e a "Hora educativa", quando não a "Hora universitária". É preciso ressaltar, contudo, que, atualmente, uma nova historiografia está revisitando o período, demonstrando que as canções exaltando a "malandragem" permaneciam sendo cantadas e compostas, apesar de toda a censura, à margem do regime autoritário.

Fica evidente, portanto, que a Rádio Inconfidência constituiu-se, assim como as demais estações, em veículo divulgador da ideologia estadonovista, uma vez que, de acordo com os documentos de época analisados, ela sempre transmitiu os discursos do presidente, bem como de seu interventor em Minas Gerais, além de apresentar uma programação elaborada nos moldes da ideologia produzida, àquela altura, pelos intelectuais que assessoravam o presidente.

\section{A questão do conteúdo das composições no Estado Novo:}

o samba exaltação ao Brasil e ao trabalho versus o elogio à malandragem

Parece ponto pacífico entre a maioria dos historiadores estudiosos do período que Getúlio Vargas não mediu esforços na construção de um estereótipo de homem novo: o trabalhador brasileiro, além de tentar desenvolver a ideia de nação e, via Estado, acirrar os ânimos nacionalistas.

$\mathrm{Na}$ construção desse ideário, o Estado Novo acabou por se utilizar dos compositores populares e das artes de uma maneira geral, além de desenvolver um forte aparato propagandístico que não deixou de lado o novo meio de comunicação da época: o rádio. Nesse sentido, as cançóes produzidas e difundidas pelo rádio à época, tornaram-se objeto de pesquisa de uma historiografia que, ainda hoje, discute, sobretudo, a valorização do trabalhador brasileiro e o elogio a Getúlio, nessa produção musical, explicitando as relações entre música e política no Estado Novo. Exaltação do trabalho e ufanismo nacionalista eram as palavras de ordem, e o Estado, por meio, principalmente, do DIP, incentivou os sambistas a comporem sambas de elogio ao trabalho e contra a malandragem.

É inegável a característica de propaganda trabalhista e governamental realizada nessa época e também fica patente o fato de que o rádio se transformara em instrumento de propaganda, não apenas comercial, mas, política e ideológica. Como toda a imprensa, o rádio e as músicas ficaram sujeitos à rigorosa censura durante o Estado Novo. Com o advento da ditadura, em 1937, até sua queda, em 1945, o tom predominante na radiodifusão foi dado pela presença intervencionista do Estado. A questão aqui é saber até que ponto se deu essa intervenção do Estado e onde aparecem as "astúcias" dos ouvintes, operários da mina de Morro Velho, que também possuía seus compositores, mineiros-artistas, boêmio-operários?

O Estado investiu em projetos grandiosos e foi esse o caso da criação de serviços de radiodifusão, comunicação e canto coral, todos eles instrumentalizadores de uma imagem idealizada pelos intelectuais a serviço de Getúlio, que queriam construir a imagem de um Brasil integrado - orgânico e harmônico - capaz de homogeneizar as diferenças inerentes à sociedade de classes.

Assim, no momento de afirmação do capitalismo, o projeto cultural do Estado apropriou-se do nacional, enquanto veículo do popular, negando até certo ponto a diferença e a pluralidade. Mas o que será que os "trabalhadores do Brasil" pensavam a esse respeito? Será que eles percebiam que o Estado Novo de Getúlio Vargas negava a diferença e a pluralidade? Será que, realmente, a ideologia getulista conseguiu se sobrepor à malandragem, desde o início, cultivada no samba e no carnaval brasileiro? Até que ponto a ideologia de construção desse trabalhador brasileiro, do homem novo, neutralizou o malandro, presente no samba e no imaginário carnavalesco brasileiro? É possível considerar as canções de exaltação à figura do malandro, do boêmio, uma transgressão, uma espécie de antidisciplina, de pequena 
resistência ao controle ideológico do Estado? Cantarolar malandragens cotidianas poderia significar, pelo menos ao nível do simbólico, uma antidisciplina? Se, antes, examinei como o controle das redes de radiocomunicação estava atrelado ao poder central do Estado, agora, parto da hipótese de que o Estado fracassou, pelo menos parcialmente, em seu intento de erradicar a malandragem como um tema caro ao mundo do samba e da música popular.

O Estado Novo deixou marcas profundas na música popular brasileira e foi durante os chamados "carnavais da guerra" que as escolas de samba assumiram efetivamente, nos seus enredos, o tom apologético e grandiloquente que até hoje aparece. Foi, ainda, ao longo desses anos que Ari Barroso "sinfonizou" o samba, conforme assinala José Miguel Wisnik, ${ }^{7}$ tornando-se uma espécie de Villa-Lobos do gênero. Contudo, ao estudar a história da Rádio Inconfidência, observei forte contraposição a esses ditames advindos dos governos central e estadual.

Assim, pude observar como, apesar de todo o controle sobre a sociedade, a cultura da malandragem permaneceu. Nesse sentido, pode-se afirmar, com Jorge Ferreira, que:

o controle total do Estado sobre a sociedade é impossível, mesmo no caso de regimes políticos definidos como "totalitários", a exemplo da Alemanha nazista e da União Soviética na época de Stalin. Os mecanismos de controle social em nenhuma situação são completamente eficientes e muito menos capazes de controlar as mentes dos indivíduos. Elegendo estratégias de vida a partir de seus interesses materiais e simbólicos, as pessoas aceitam alguns deles, ignoram outros e, na medida de suas possibilidades, repudiam aqueles que os prejudicam. ${ }^{8}$

A seguir, com a narrativa de Waldir dos Santos - trabalhador da mina de Morro Velho, entrevistado por ocasião do desenvolvimento desta pesquisa - pretendo traduzir essa discussão, por meio de sua memória sobre o repertório das rádios, em cujas ondas o imaginário dos brasileiros viajava...

\section{O cotidiano do rádio em Nova Lima}

Comecemos por assinalar que o poder seria, a priori, o poder do Estado, ou seja, ele estaria localizado no aparelho de Estado, a um ponto tal que mesmo os poderes privados não teriam senão uma dispersão aparente, nada mais sendo que aparelhos de Estado especiais. No entanto, as teses foucaultianas já demonstraram que, pelo contrário, o Estado surge como um efeito de conjunto ou uma resultante de uma multiplicidade de engrenagens e de focos que se situam a um nível completamente diferente, e que constituem, em si mesmos, uma "microfísica do poder". Não somente os sistemas privados, entretanto, mas também peças explícitas do aparelho de Estado possuem, ao mesmo tempo, origem, procedimentos e exercícios que o Estado sanciona, controla, ou até aos quais se limita a dar cobertura, sem sequer mesmo os instruir. Parece ser esse o caso do rádio no Estado Novo, conforme pude perceber, em parte, no depoimento de Waldir dos Santos sobre o rádio daquela época.

Por meio dos relatos orais é possível observar como os operários mineiros interpretaram a ação do Estado Novo, em termos de sua interferência nos veículos de comunicação radiofônicos. Waldir dos Santos, por exemplo, ao relembrar o que ouvia no rádio, as músicas que eram divulgadas, quando e onde foi a inauguração da Rádio Inconfidência, diz que, em sua opinião, a censura, a intervenção do governo no rádio, ocorreram, sim, mas de forma muito leve:

Era isso que eu sentia pelo presidente: admiração. Eu até me recordo que nas rádios havia censura. Era na época da ditadura, mas era uma censura muito branda. E do ponto de vista humorístico em minha opinião não havia censura. O próprio Getúlio Vargas achava engraçada a audácia dos chargistas, humoristas, dos músicos, compositores, no seu governo.

Além do que, Vargas apoiava a cultura, atuava muito nas artes e nas músicas. Ele deu muito apoio. Assistia tudo. Quando se lançava alguma revista musical no Rio ou em São Paulo, ele ia lá, subia ao palco e congratulava diretamente o cidadão. Falava diretamente com o povo. Todo mundo aplaudia e ele suportava todas as brincadeiras que os artistas faziam com ele. Ele tinha espírito esportivo, era alegre. Mas isso é porque os críticos faziam as músicas com um tom humorístico, irônico, não de agressão. Eles também procu- 
ravam agradar ao público e o público gostava de Getúlio. Eles também faziam músicas para agradar, que falavam bem de Getúlio, brincavam com ele de modo carinhoso. Por exemplo, quando teve a eleição, bem depois do Estado Novo, em 51, ele ganhou. Então, os músicos fizeram: "Bota o retrato do velho outra vez, ponham no mesmo lugar..."

Conforme seu relato, ele acabou por se tornar um getulista convicto e comenta que, naquela época, o povo era feliz e todos os pobres brasileiros gostavam de Getúlio e de sua forma de governo. O autoritarismo parece não ter existido para o entrevistado. Ele defende as leis trabalhistas e confirma que, naquele momento, as músicas falavam de trabalho, elogiavam o Brasil e suas belezas, o que acaba por comprovar a hipótese de que, além da exaltação ao trabalho, a questão do nacionalismo estava presente:

A Era de Ouro do rádio começou no Estado Novo, foi no governo de Getúlio Vargas. Ninguém podia falar mal do governo porque ia preso mesmo, era uma ditadura. Mas a repressão era muito branda, não se compara com a dos militares de 64. A repressão era branda, principalmente se pensarmos nas classes menos favorecidas. Os que sofreram mais foram os poderosos, porque Getúlio era contra a política entreguista. Todo o trabalhador era adepto de Getúlio. Ele promoveu uma coisa extraordinária que foi a consolidação das leis do trabalho, porque deu ao trabalhador o direito de se defender contra a escravidão, que era imposta através dos donos do dinheiro. As rádios apoiavam Getúlio. Eu me recordo mais da Rádio Nacional que era do governo, era a mais ouvida, a mais difundida. Agora as outras eu não me recordo muito bem... Tinha a Excelsior, mas aqui em Minas, eu me lembro da Rádio Inconfidência, que também era do governo de Minas. Eu me lembro da inauguração. Foi antes do Estado Novo, acho que em 1936, e foi no prédio da Feira de Amostras. (...) Tinha também a Rádio dos Diários Associados. Acho que era a Rádio Mineira, e a PRC-7, ambas de propriedade do Assis Chateaubriand. Mas não estou certo. O que tenho certeza é que a Rádio Inconfidência era a rádio oficial do governo. ${ }^{10}$

Waldir também se lembrava de cançóes que discordavam do ideal de homem novo de Getúlio, recordando de uma que traz a fala de um marido que manda a esposa fazer o café e a marmita, ir jogar no bicho e trazer o troco, porque ele precisa do dinheiro para ir ao jogo no Maracanã. Apesar de a tônica do regime ser o trabalho, a tentativa de formação de uma ideia de nação com ordem para o progresso, os compositores mantinham acesa a chama do carnaval, da boêmia, ou seja, da malandragem. O próprio depoente ora nos conta sobre músicas de exaltação e elogio ao trabalho, ora sobre canções nas quais o tema do malandro está presente:

Tinha música de todo o tipo. A maioria, na época do Estado Novo, era de elogio ao Brasil, suas belezas, as coisas boas de cada Estado. "Aquarela do Brasil", de Ari Barroso é desta época. Foi na ocasião de Getúlio que fizeram aquela música chamada "Barracão de Zinco". Eram sambas de exaltação ao Brasil. Essa música era do Alcir Pires, um grande compositor da música popular. Nessa ocasião apareceu muita composição de exaltação ao Brasil. "Ave Maria no Morro" saiu nesta época. Quem cantou foi Dalva de Oliveira. As músicas geralmente abordavam esses temas de exaltação ao Brasil, das suas belezas, patriotismo, falavam sobre o povo brasileiro. Aliás, as próprias leis trabalhistas influenciavam nas músicas. A própria "Aquarela do Brasil" exalta o trabalhador brasileiro. Era uma ocasião em que o povo estava alegre, feliz. Um povo feliz é um povo que canta. Eu mesmo fiz uma música de exaltação ao trabalho, influenciado pelo Getúlio. Chama-se "Rosário de Felicidade":

Para que a vida seja um rosário de felicidade

É preciso ter fé em Deus, Saúde e Mocidade

Ter disposição de trabalhar todo dia.

E uma bela mulher que faça companhia

Com saúde e mocidade

Fé em Deus que é o nosso guia

Com toda felicidade e uma vida em harmonia

Com carinho e trabalho

Ter uma vida pessoal

Um pouco com Deus é muito 
Um muito sem Deus é nada”.

Essa música eu nem difundi. Fala só de trabalho, de amor e carinho, na qualidade de operário que eu era. Havia muitas músicas falando de trabalho, de trabalhador, de operário:

"O bonde São Januário

Leva mais um operário

Sou eu que vou trabalhar".

Depois de Getúlio, o sujeito falava menos de malandragem e mais de trabalho. ${ }^{11}$

O rádio era muito difundido em Nova Lima: os homens ouviam noticiário, futebol, música, e as mulheres escutavam novelas e músicas. Waldir dos Santos também foi um compositor e ouvinte assíduo das rádios naquela época:

Foi também na época dos bailes do Retiro e do Vila Nova que eu comecei a compor meus sambinhas. Na ocasião, eu fiz uma espécie de hino para Nova Lima. Eu acho que ninguém sabe a letra desse hino. Eu não achei muito bom. Foi quando eu voltei para Nova Lima, década de 30, voltei em 32, para Nova Lima. Eu devo ter composto esse hino em 35. "Nova Lima, linda cidade criança, berço de Augusto de Lima, terra do amor e da esperança. Conjuga as cores da bandeira: o azul do céu, o verde da esperança e o ouro, maravilha das estrelas..."Acho que isso já foi na época do Estado Novo de Getúlio. As rádios que se ouviam aqui eram principalmente as rádios cariocas, mas havia rádios mineiras como a Atalaia, a Inconfidência. Eu ouvia principalmente a Rádio Nacional, do Rio. A rádio Nacional tinha programas ao vivo, de auditório... Tinha o do Alencar, que era animador. Tinha o programa do César Ladeira, que era locutor, mas não animava programas de auditório. Eu me lembro que havia disputas entre cantoras, como a Marlene e a Emilinha, e na ocasião, houve também uma [disputa] musical entre o Noel Rosa e um outro compositor que agora não lembro o nome. Ele cantava para o Noel: "Quem é você que não sabe o que diz. Meu Deus do céu, que palpite infeliz. Salve Estácio, Salgueiro e Mangueira, Oswaldo Cruz e... que sempre se deram muito bem...” Não me lembro o resto da música. Só sei que o Noel era de Vila Isabel e era divulgador das belezas de lá. ${ }^{12}$

A entrevista do mineiro também é rica ao relatar alguns momentos específicos, nos quais o rádio foi de fundamental importância, justamente por trazer, além dos programas de entretenimento, aqueles de caráter informativo e matérias de caráter político, como as que ouviu durante a Segunda Guerra Mundial, momentos que se iluminam no seu processo de rememoração:

Havia também os programas de caráter mais político. Por exemplo, quando ocorreu a Segunda Guerra Mundial, o Brasil entrou e todos nós ouvíamos diariamente notícias através do César Ladeira, que era o locutor que lia todas as notícias sobre o movimento de guerra. A participação do Brasil no momento em que declarou guerra à Alemanha, ao Eixo, quando tiveram movimentos de protesto contra os alemães e italianos no Brasil inteiro. Cesar Ladeira noticiava as quebradeiras. Porque foi uma quebradeira geral. Em Nova Lima teve um quebra-quebra terrível. A rádio foi muito importante. Outro evento que a rádio teve muita participação foi na inauguração da estátua do Cristo Redentor, no Rio. Parece que foi um italiano que trabalhava com rádio que conseguiu iluminar a estátua do Cristo. Acho que o sujeito se chamava Marconi, não estou bem lembrado... ${ }^{13}$

Entre a memória e seu duplo, tão necessário, o esquecimento, a rede da recordação tecida pelo boêmio operário, com contradições inerentes ao relembrar de um senhor de quase 90 anos, propõe uma reflexão sobre o cotidiano e o papel do rádio em Nova Lima e no Brasil, permitindo que a história social se entrecruze com a história individual, isto é, com o olhar subjetivo, fragmentado, de um trabalhador brasileiro que viveu e reviveu - no momento de sua entrevista - o Estado Novo e os anos dourados do rádio no Brasil.

\section{O lazer em Morro Velho: maneiras de fazer dos operários entre o samba e o trabalho}

Tende-se a considerar as práticas do lazer operário, a princípio, não como válvula de escape, alienação, ou outra coisa do gênero, mas como transgressão, uma subversão restrita da ordem, exercida por sujeitos que, em sua maioria, estavam muito cientes de sua condição de vida oprimida e sofrida. No 
cotidiano dos operários de Morro Velho era constante a presença de determinados elementos festivos, como a boêmia, a música, o futebol, o carteado, as festas religiosas, as lutas de boxe, o rádio... É possível que essas manifestações culturais dos mineiros de Nova Lima fossem um contraponto à situação terrível que viviam no local de trabalho, no sentido de um contraste entre vida e morte. Contraste entre a possibilidade de morte dentro da mina, possibilidade constante, por um lado; e, por outro, possibilidade de celebrar a vida com prazer nas festividades, nos momentos de descontração? Ou seriam essas manifestações culturais uma forma de resistir, de transgredir, de subverter, mesmo que de forma subliminar, esse sofrimento?

Muitas práticas cotidianas (falar, ler, circular), de acordo com Michel de Certeau, são do tipo tático e, também, de modo mais geral, uma grande parte das "maneiras de fazer", isto é, vitórias do "fraco" sobre o mais "forte" (os poderosos, a doença, a violência das coisas ou de uma ordem etc.): "pequenos sucessos, artes de dar golpes, astúcias de 'caçadores', mobilidades da mão-de-obra, simulações polimorfas, achados que provocam euforia, tanto poéticos quanto bélicos." ${ }^{14}$ Nesse sentido, beber cerveja depois do trabalho árduo na mina constituía-se em uma das "maneiras de fazer" desses operários que acabavam transgredindo as ordens do patrão inglês.

As festas, a boêmia e o carnaval, por meio de suas múltiplas representaçôes, parecem ter tido esse papel. Desdobravam-se num espaço de conflito, de competiçóes cotidianas, no qual se vivenciava uma divisão social, com um clube de operários e outro dos ingleses, onde só entravam indivíduos brancos. Essa separação era questionada, por outro lado, na representação do Congo, ou no Carnaval de rua, onde esses segmentos oprimidos podiam vestir-se como deuses, ou heróis, e expor os modelos de gestos bons ou maus, utilizáveis a cada dia. De acordo com Michel de Certeau, trata-se de

discursos estratégicos do povo. Daí o privilégio que esses contos concedem à simulação/dissimulação. Uma formalidade das práticas cotidianas vem à tona nessas histórias, que invertem frequentemente as relações de força e, como as histórias de milagres, garantem ao oprimido a vitória num espaço maravilhoso, utópico. Este espaço protege as armas do fraco contra a realidade da ordem estabelecida. Oculta-se também às categorias sociais que "fazem história", pois a dominam. E onde a historiografia narra no passado as estratégias de poderes instituídos, essas histórias "maravilhosas" oferecem a seu público (ao bom entendedor, um cumprimento) um possível de táticas disponíveis no futuro. ${ }^{15}$

Não só no caso dos contos e das lendas a que se está referindo Michel de Certeau, mas no cotidiano dos operários que dançavam a Congada e representavam a chegada do Rei Congo, como se verá a seguir, ou que brincavam o Carnaval vestidos de reis, deuses e patrões, observa-se verdadeiras transgressões, mesmo que num espaço até certo ponto controlado, pois era a empresa, a Saint John D’El Rey que financiava a maioria das festividades, ao lado da Igreja.

\section{A festa e o divertimento como transgressão restrita}

Do que falam as festas? O que representam? Sem dúvida, as festas - sejam elas da ordem do religioso, do sagrado, ou do profano -, geralmente, acabam por sintetizar, simbólica e materialmente, diferentes elementos que permeiam a vida cotidiana. Nelas, a estrutura social acaba por ser dramatizada, ou seja, a festa mostra o papel do econômico, do político, do religioso e do estético no processo de transformação e/ou continuidade da cultura de um povo, de um lugar, de determinada cultura popular. Existe, desse modo, uma continuidade entre a festa e a vida cotidiana, o tempo do trabalho.

Por que são feitas as festas? De acordo com Néstor García Canclini,

fazem-nas também para consolidar as relações afetivas comunitárias, o pertencimento à comunidade dos que partiram e regressam para celebrar. Reinvenção interna obrigatória do excedente econômico, catarse obrigatória daquilo que não pode vir à tona no trabalho que é realizado em condições de opressão, mas que é também regulado na sua irrupção festiva para que não prejudique a coesão permanente: a festa não é a 
liberação desregrada dos instintos que tantos antropólogos e fenomenólogos imaginaram, mas um lugar e um tempo delimitados no qual os ricos devem financiar o prazer de todos e o prazer de todos é moderado pelo "interesse social". As paródias ao poder, o questionamento irreverente da ordem (mesmo nos carnavais) é consentido em espaços e momentos que não ameaçam o retorno posterior à "normalidade". ${ }^{16}$

É justamente esse aspecto de liberação daquilo que não pode vir à tona no trabalho, ao lado das paródias ao poder, ao questionamento da ordem e à inversão desta, que deve ser considerado quando se pensa nas "maneiras de fazer" desses operários, suas pequenas antidisciplinas. Mesmo que estas, pelo que indica a fala do entrevistado, fossem ainda bastante restritas e permeadas por limitaçóes da própria vida cotidiana, dos limites de espaço e tempo e, afinal, pelo fato de que algumas dessas manifestaçôes de caráter festivo eram financiadas pela empresa. Tanto no caso das festas religiosas quanto no das carnavalescas, deve-se destacar que ambas possuem funções políticas e sociais de coesão e reforço coletivo. Ambas as festividades, principalmente a carnavalesca, acabavam por dramatizar a realidade social daqueles operários, daquelas prostitutas, dos patrôes-de-mina, enfim, dos moradores da cidade de Nova Lima. Porém, deve-se deixar claro que a festa não é só espetáculo ou lugar de catarse, é principalmente lugar de transgressão, de antidisciplina. Pode ser até mesmo o lugar da revolução, ou da reafirmação desta, como nas festas da Revolução Francesa. ${ }^{17}$

Ao analisar "as razões do desgoverno" nas festividades de Lyon no início da França Moderna, Natalie Zemon Davis demonstra claramente que a festa, apesar de aparecer em certos momentos como transgressão restrita (muitas dessas festas eram patrocinadas pelo clero, como a Festa dos Bobos, por exemplo), com todas as restrições, é importante veículo de contestação e crítica da ordem social imposta:

"Às vezes pode ser útil dar permissão ao povo para fazer palhaçadas e alegrar-se", dizia o advogado francês Claude de Rubys, no final do século XVI, "para impedir que, ao controlá-lo muito rigorosamente, ele caía no desespero. Abolidos esses jogos alegres, em vez de tomar parte neles as pessoas vão para as tavernas, põem-se a beber, a tagarelar, com os pés inquietos sob a mesa, e a analisar o Rei e as princesas... o Estado e a Justiça, e ficam imaginando panfletos difamatórios e escandalosos”. A visão de Rubys é tradicional, mas ela nos diz mais sobre a mentalidade dos magistrados urbanos do que sobre os usos efetivos da diversão popular. Espero mostrar que, em vez de ser uma mera "válvula de escape", desviando a atenção da realidade social, a vida festiva pode, por um lado, perpetuar certos valores da comunidade (até garantindo a sua sobrevivência) e, por outro, fazer a crítica da ordem social. O desgoverno também pode ser rigoroso em sua análise do rei e do Estado. ${ }^{18}$

\section{Boêmia}

Waldir dos Santos tinha uma intensa vida boêmia. Participava de bailes, do carnaval, ia aos bares da cidade de Nova Lima, ao cabaré. Pequenas transgressões... Seria isso uma forma de sublimar o sofrimento da mina, uma válvula de escape, ou uma resistência, no sentido de antidisciplina cotidiana, nas suas "maneiras de fazer"?

Dentre os espaços de lazer da cidade de Nova Lima, encontrava-se o Cabaré e Bar do Aziz. Espaços destinados à boêmia, ao divertimento, frequentados por operários e patrôes, ponto de encontro cotidiano, um verdadeiro mundo dentro do mundo. Nova Lima não era só trabalho, não era só sofrimento no interior da mina; era também diversão, prazer, festa.

Nós tínhamos lugares certinhos para ir beber. Até as 10 horas a gente tomava lá pelos botecos de Nova Lima, mas das 10 horas até as 5 horas da manhã era a zona. Tinha o bar do Aziz. Era perto da sede do Retiro, mais ou menos no centro. Perto da Rua da Lagoa, eu não estou lembrando o endereço exato. O Bar do Aziz era o bar onde a rapaziada jovem daquela época se reunia e a minha turma se encontrava toda noite para contar histórias, namoros. Quando tinha baile na Sede do Retiro, era no bar do Aziz que a gente se reunia para ir para o baile. ${ }^{19}$ 
A prática do uso do álcool é bastante comum entre a classe operária, especialmente a ida ao bar depois do expediente. O bar do Aziz era o ponto de encontro dos homens, trabalhadores ou "malandros" da cidade. De acordo com Pierre Mayol, ${ }^{20}$ o bar pode ser considerado, sob certos pontos de vista,

como o equivalente da "casa dos homens" das sociedades tradicionais. "Salão do pobre", é também o vestíbulo do apartamento onde os homens se encontram por algum tempo na volta do trabalho antes de irem jantar em casa; o café é uma "chicane", um ardil, uma câmara de compensação, da atmosfera social, entre o mundo do trabalho e a vida íntima. ${ }^{21}$

O café do cotidiano parisiense, ou o vinho do bairro operário, analisado por Mayol no segundo tomo de $A$ invenção do cotidiano, pode ser aqui, no caso de Nova Lima, substituído pela cerveja e pela cachaça. Entre o mundo do trabalho e a vida íntima, o bar onde se bebe cerveja depois do trabalho está sempre cheio. É também um lugar ambíguo, ao mesmo tempo tolerado por ser a "recompensa" de um dia de trabalho, e temido, por causa da propensão ao alcoolismo que parece autorizar. Por isso, nem todos os operários bebiam.

Entretanto a problemática do beber que aparece quando se pensa na vida cotidiana desses operários é fundamental para se refletir sobre as "maneiras de fazer" discutidas neste artigo. Não quero aqui justificar a boêmia, mas entender o significado simbólico do beber, do tomar cerveja, cachaça, práticas que merecem atenção. O discurso sobre a cerveja, a cachaça, bem como outras bebidas alcoólicas se acha dentro de uma ambivalência indisfarçável: o prazer em beber tende sempre para o limite do beber em demasia. A bebida contém intrinsecamente a possibilidade de um desvio, de um excesso no consumo; pode ser a origem de uma viagem sem retorno; o abuso da bebida pode desembocar na enfermidade, na destruição, na morte. ${ }^{22}$ Daí talvez o medo de alguns desses operários em experimentar a embriaguez: de um lado, a constante presença da morte dentro do mundo do trabalho, na mina, e, de outro, a possibilidade de a morte vir igualmente do outro lado, pelo excesso. Todos têm em mente a imagem social do alcoólatra, do marido beberrão que espanca a mulher etc. Por isso, é preciso que haja algum rodeio, pois este permite, precisamente, afastar-se do excesso da bebida, para se autorizar a bem beber, sempre "sóbrio". Waldir dos Santos, por exemplo, se orgulhava da boêmia feliz, do saber "virar o copo" na hora certa e voltar para casa ainda sóbrio.

Essa estratégia - que visa afastar qualquer suspeita que possa pesar sobre o bebedor - repousa sobre a pretensão de um saber-beber. Ao discurso repressivo, seja dos ingleses, seja daquilo que era ensinado desde os tempos de escola ou na Igreja, contrapunha-se um discurso que exaltava a virtude da temperança, o savoir-faire da degustação qualitativa e quantitativa, conforme explica Mayol. Na verdade, para o operário, o problema não era beber, era saber parar. E insistir para que todos bebessem era nada mais nada menos do que forçar para que todos celebrassem a alegria dos que bebiam.

Como o vinho dos operários franceses, a cerveja e a cachaça dos bares das cidades operárias mineiras passavam a simbolizar a antitristeza, a face festiva da vida cotidiana desses trabalhadores. É uma economia da liberalidade. A cerveja e/ou a cachaça eram, portanto, o eixo principal de um intercâmbio, o mediador da palavra, do reconhecimento, parte constituinte de uma cultura popular operária, urbana, para a qual a bebida contribuía até mesmo na formação de valores de identificação, essenciais, que giravam principalmente em torno de práticas de solidariedade. Por isso, unir-se em torno da bebida propiciava o encontro, as trocas, a efetivação de práticas de solidariedade entre esses operários. O bar era o local onde ocorria a afirmação das diferenças e das similitudes. Quem bebia e quem não bebia; quem conseguia se alegrar, ou não, perante a tristeza social dos que trabalhavam em terríveis condições, no interior de uma mina, onde era constante a ameaça do fim. A cerveja e a cachaça são um convite à viagem para a festa; mas, como assinala Mayol:

não se pode ir até o extremo, até a vertigem central, mortal, que tem, no entanto, como premonição a troca inicial, simbolizada pelo ato de encher os copos, o tim-tim e a prova do primeiro gole. É que o fantasma da desordem absoluta, a abolição de todas as diferenças, pessoais, sexuais, culturais que a festa do vinho põe 
em cena - a festa dos loucos - não é realizável em parte alguma na vida social. A conveniência exige que se pare a tempo, a fim, precisamente, de permanecer no tempo. ${ }^{23}$

Já bastava, portanto, a presença da morte no mundo do trabalho. A bebida não podia sequer representar essa possibilidade. Ela devia ser tão somente momento de celebração da vida. Portanto, quer-se aqui ressaltar seu valor simbólico. Trata-se de se acentuar o valor comunal, coletivo, que a bebida trazia em si e, nesse sentido, motivo de celebração da vida, da alegria. O lugar da bebida era o lugar da união dos operários, momento de antidisciplina, no qual emerge a negação da disciplina imposta pelos ingleses na mina. A cerveja, por exemplo, simboliza a soberania e é também símbolo da vida. ${ }^{24} \mathrm{O}$ ato de beber converte-se, assim, em um cerimonial, com toda a sua simbologia. Beber à saúde de alguém, erguer o brinde de honra, são atos indispensáveis no protocolo social: celebração da vida, momento de união e de formação/consolidação da identidade coletiva.

Ao lado da bebida em si, a boêmia aparecia também no Cabaré, na convivência com as prostitutas. Waldir dos Santos considerava-se um boêmio não só porque frequentava o bar do Aziz, mas principalmente por ter vivido a noite da cidade de Nova Lima. É interessante tentar apreender um pouco das práticas noturnas dos habitantes da cidade em seu relato. Por intermédio dele foi possível encontrar elementos do cotidiano, não só dos operários, mas de todo um outro mundo: o do cabaré, habitado por prostitutas, patrôes de mina, forasteiros. Além de descrever as terríveis condições de vida das prostitutas de Nova Lima, também se pode observar a repressão, o controle dos outros pontos de encontro dos operários:

Quando voltei para Nova Lima, aos 16 anos, eu já caí no "fandango". Eu dançava muito bem e comecei a frequentar a Sede do Vila Nova, a sede do Retiro, e logo parti para o Cabaré. Eu não saía da zona boêmia. Nesse tempo eu trabalhava no final do processo de apuração do ouro. Trabalhava no laboratório e tinha um horário especial, com uma hora a menos. Eles davam vantagem para o trabalho de risco e o laboratório já era considerado zona de risco, por influência das leis de Getúlio Vargas. Eu saía de lá do laboratório e ia direto para a zona. Ficava das 3 horas até às 6 horas da tarde com as mulheres na zona. De tarde, é, de tarde. Quando era 6 horas eu ia em casa, tomava banho, jantava, vinha para a cidade, namorava, tomava minha cervejinha. Quando dava 10 horas eu voltava para a zona. Eu ia para o Cabaré. Era hora da gente tapear os coronéis. Eu promovia no salão do Cabaré aquelas prostitutas que dançavam bem. Elas pagavam meu ingresso e eu dançava com elas. Os coronéis que estavam em volta, bebendo cerveja, falavam: "eu vou roubar aquela mulher daquele menino". Chamava e ela acompanhava ele. E eu pegava outra e saía com ela. Quando era na madrugada, eu ia buscar o meu dinheiro, ela me dava parte do que arrecadava. Eu servia de atração porque dançava muito bem. Eu vivi nessa vida dos 16 aos 25 anos. Porém, certa ocasião, eu tive medo de adoecer. Eu tive uma probabilidade de pegar uma carga de doença venérea muito grande. Eu tinha uma sorte incrível, nunca pegava nada, e olha que eu fazia amor com todas... ${ }^{25}$

É interessante perceber, também, como se dava a repressão ao principal ponto de prostituição da cidade:

No cabaré era comum a polícia fechar por qualquer denúncia. E eles usavam de violência. Todo mundo que saía de lá apanhava. Era terrível! Uma ocasião, eu estava em frente ao cabaré, que era uma estrada. Tinha a entrada do cabaré e em frente tinha aqueles casebres que as mulheres alugavam para fazer vida. E eu tinha entrado com uma mulher em frente. Quando eu ouvi aquela balbúrdia em frente, da rua, nós ficamos da greta da janela olhando. Tinha um crioulo soldado que tinha o apelido de Coice de Mula. Ele tinha um soco, que qualquer um caía no ato. Ele ficou na porta do cabaré. Chegava o camarada ele dava a busca. Não tinha arma, mas mesmo assim ele batia no sujeito. O camarada caía. Quando levantava, os outros soldados metiam o pé na bunda dele. Faziam corredor polonês. Todo homem que saiu do cabaré essa noite apanhou. E eu de lá da janela do outro lado só olhando. Eu podia estar nessa também, mas eu tinha o Santo forte, graças a Deus. (...) Eu fui um boêmio de lascar... ${ }^{26}$

A presença da boêmia também é apresentada sucintamente no trabalho de Yonne Grossi. Ao examinar a questão salarial dos operários, ele traz o depoimento de um anônimo que conta o que era feito com o salário, já no dia do pagamento, no caso dos operários solteiros: 
O mineiro solteiro recebia o dinheiro e ia procurar bares e mulheres. Havia um fluxo de mulheres de fora que vinham para pegar o dinheiro dos mineiros na boêmia. Tinha uma chefete que controlava a zona: selecionava as melhores mulheres para os encarregados. Os carreiros eram prejudicados; ficavam com as mulheres piores. Muitos vinham para Belo Horizonte para gastar o seu pagamento. ${ }^{27}$

E Waldir irá confirmar essa afirmação, ao contar que "pagavam bem, quase em libras. Tinham ordenado bom, os feitores. Eles é que mantinham o Cabaré de Nova Lima em alta, o meretrício. Porque os broncos, ganhando uma nota violenta, eram os 'donos do pedaço'”.

\section{Carnaval}

Dentre todas as formas de lazer, o Carnaval era a celebração mais festiva dos mineiros. Havia a formação de blocos e ensaios durante todo o ano, em casas de família.

Existiu um bloco idealizado pelos mineiros, que talvez fosse um esboço de cultura da classe. A fantasia consistia na indumentária usada na mina. $\mathrm{O}$ canto e os gritos expressavam a situação do subsolo. $\mathrm{O}$ bloco reproduzia o ambiente de trabalho: o carreiro imitava o feitor, o "sambado", o maricas, entre outros. Levava também uma ala dos pica-paus e outra dos trabalhadores do tráfego. Desfilavam em Nova Lima, Belo Horizonte e cidades vizinhas. ${ }^{28}$

De um lado, esse tipo de manifestação parece ser algum tipo de estratégia, de prática, de antidisciplina. Havia, também, blocos como o dos "Prontos", "Cai-cai", "Turunas", integrados por outras camadas sociais, como comerciários e bancários, e o bloco das prostitutas, em parte financiado pelos feitores. O carnaval em Nova Lima, de acordo com Grossi, era um entregar-se à afirmação do prazer, o que apagava por momentos as diferenças sociais. ${ }^{29}$

Esse olhar sobre a festa carnavalesca remete-nos a outro tempo, tempo medieval, tempo do renascimento. As festas populares sempre desempenharam importante papel social no sentido duplo de protesto e de controle. Um exemplo foi a grande revolta da Catalunha que teve seu início em junho de 1640, no Corpus Christi, uma das maiores festas espanholas.

O Carnaval, como tudo indica, não se resumia à festa de janeiro/fevereiro. $\mathrm{Na}$ Espanha, por exemplo, o Primeiro de Maio era como o Carnaval, comemorado com batalhas e casamentos simulados; o verão também tinha seus carnavais, principalmente Corpus Christi e a celebração de São João Batista. A festa de Corpus Christi, que se difundiu pela Europa a partir do século XIII, era um dia de procissões e peças; na Inglaterra dos finais da Idade Média, os mistérios eram apresentados nas praças do mercado de Chester, Conventry, York e outros lugares. Também na Espanha, Corpus Christi era o grande dia de apresentação de peças religiosas, mas as festividades eram permeadas de elementos carnavalescos. Elaborados carros alegóricos passavam pelas ruas, transportando santos, gigantes e, o mais importante, um enorme dragão - identificado, em termos cristãos, com o mal, derrotado pelo povo de Deus, conforme se lê no Apocalipse -, enquanto a mulher às suas costas supostamente representaria a prostituta da Babilônia. Os ouvidos da multidão podiam ser tomados por sons de fogos de artifício, gaitas de foles, pandeiros, castanholas, tambores e cornetas. Os diabos tinham um papel importante a desempenhar, dando cambalhotas, cantando e travando batalhas simuladas com os anjos; o bobo tinha oportunidade de bater nos circunstantes com a sua bexiga. A partir daí, pode-se entrever outra leitura que servirá de ponte para chegar ao "grotesco", ao mundo às avessas do Carnaval, quando operários passam a patróes de mina e vice-versa...

Segundo Michael Bakhtin, um dos problemas mais interessantes da história da cultura é o problema do carnaval, o problema da carnavalização. De acordo com esse autor,

o carnaval é um espetáculo sem ribalta e sem divisão entre atores e espectadores. No carnaval, todos são participantes ativos, todos participam da ação carnavalesca. Não se contempla e, em termos rigorosos, nem 
se representa o carnaval, mas vive-se nele, e vive-se conforme as suas leis enquanto estas vigoram, ou seja, vive-se uma vida carnavalesca. Esta é uma vida desviada da sua ordem habitual, em certo sentido uma "vida às avessas", um "mundo invertido" (monde à l'envers). ${ }^{30}$

As imagens do carnaval, portanto, são biunívocas, englobam os dois campos da mudança e da crise: nascimento e morte, bênção e maldição, elogio e impropério, mocidade e velhice etc. Existem inúmeras imagens ambivalentes, o riso é uma delas; nele se fundem o escárnio e o júbilo. "Na forma do riso resolvia-se muito daquilo que era inacessível na forma do sério. Na Idade Média, sob a cobertura da liberdade legalizada do riso, era possível a paródia sacra, ou seja, a paródia dos textos e rituais sagrados." ${ }^{31}$ No caso da mina de Morro Velho, o riso pode parecer uma paródia à situação terrível em que viviam os operários.

"Parodiar é a criação do duplo destronante, o mesmo 'mundo às avessas'. Por isso a paródia é ambivalente." ${ }^{32}$ A paródia é ambivalente, é riso e é sofrimento, tem profunda relação com a morte, no sentido de ser renovação. As condições de trabalho dentro da mina eram desumanas. Acidentes, poeira, silicose, umidade e temperaturas médias de $40^{\circ} \mathrm{C}$ eram constantes. Todos os dias era possível sair de casa e nunca mais voltar. O Carnaval pode ser visto como um momento de celebração da vida, fazendo-a paródia da própria possibilidade de morte.

Também, no caso de Nova Lima, é possível perceber uma coexistência entre a cultura séria e oficial - a dos ingleses e diretores da empresa que se segregavam em seus clubes, o Ideal e o Retiro, mantendo-se isolados da população - e a cultura cômica, popular, enfim, carnavalizada, que promove a liberação do riso e do corpo. Se entendemos que a carnavalização promove um universo desfigurado, através da visão especular, ou seja, o mundo às avessas, é possível supor que as extravagâncias desses operários durante o Carnaval em Nova Lima, ao liberar sua conduta humana de normas, possibilitavam outro espetáculo: o da transgressão, mesmo que ela se restringisse, como já foi dito, a esses espaços limitados, controlados, seja por um padre conservador, seja pela empresa, que financiando a festa, também impunha sua dominação.

É relevante observar as reminiscências de Waldir dos Santos, no que diz respeito à realização desta "festa profana":

Samba no pé era no Carnaval. Eu era carnavalesco, dançava quatro noites sem dormir, mesmo trabalhando na Morro Velho. Porque lá não parava de jeito nenhum. Mas eu dançava quatro noites sem dormir. Nos blocos havia muita rivalidade. Tinha o Caroço Encravado que era o bloco da classe média. E tinha o Sorriso, por parte do Retiro. A rivalidade do Retiro e do Vila Nova era uma coisa incrível. Seu Manoel era do Vila Nova e Niquelino do Retiro. Era uma rivalidade sem igual e os Niquelinos fizeram o Sorriso e Seu Manoel fez o Caroço Encravado. E, fora a rivalidade desses dois, tinha o Minas, que era um bloquinho pequeno que eu ia também, porque eu era eclético, ia em todos. Eu dançava bem e puxava bem o cordão, eu era baliza. Porque o passista de hoje é o baliza de ontem. Já tinha o porta-estandarte. Nessa época a bandeira do bloco vinha atrás, mas o baliza era da comissão de frente. Baliza era aquele que ia em frente, o nome diz. Eu só saía na frente, botava o samba no pé mesmo. ${ }^{33}$

\section{Considerações finais: caminhando entre a autonomia e a heteronomia}

Este trabalho pretendeu examinar as relações de poder e dominação na mina de Morro Velho no período compreendido entre os anos 1930 e 1940, abordando principalmente o espaço da cultura. A relação entre os operários e a figura de Getúlio Vargas, o lazer operário e suas "maneiras de fazer" cotidianas - festas, boêmia, cabaré, entre outras artes, "astúcias" desses operários - ofereceram elementos de análise, que permitiram compreender questóes relativas à cultura construída e vivenciada pelos trabalhadores da mineração. A análise evidenciou as antidisciplinas cotidianas, demonstrando que esses operários não eram totalmente passivos aos ditames do Estado, muito menos ao controle dos ingleses. Eles conseguiram, em parte, em seu cotidiano, dentro ou fora da mina, se apropriar dos discursos dominantes, utilizando-os a partir de suas necessidades. 
Isto posto, cabe ainda tecer algumas considerações que ultrapassam o âmbito da análise empreendida, embora o objetivo central tenha sido o de ressaltar a figura do trabalhador como sujeito muitas vezes autônomo, capaz de imprimir a sua marca no mundo que o circunda.

"O sujeito é um ser criativo". Essa afirmação de Eugene Enriquez ${ }^{34}$ faz-nos pensar no homem simples que, em seu dia a dia, em suas relações sociais, vai tecendo uma rede de ações que promovem, mesmo que minimamente, uma mudança, uma transformação: aquilo que Michel de Certeau chamaria de antidisciplina, já comentada ao longo dessas páginas. Nesse sentido, existem inúmeras práticas cotidianas (falar, ler, caminhar pela cidade, habitar, cozinhar, conversar...) que se constituem em verdadeiras ações políticas. Talvez, a partir daí, se possa afirmar que esses homens "criativos", enquanto seres que são-sendo, ou seja, que produzem e criam um social-histórico em devir, são sujeitos políticos na e da História. Porém essa afirmação pode suscitar uma discussão. Até que ponto esses indivíduos, agora considerados sujeitos "criadores da história", são autônomos em relação a esse social-histórico que a todo tempo pressiona para que cada um seja "indivíduo individualizado"? Ou seja, até que ponto pode-se pensar um sujeito político que não tenda a se prender na "massificação" causada pelo apego às identidades coletivas? Ou nessas tentativas de "massificação", essas tentativas de "controle da memória", como tendemos a ver no período Vargas?

Discuto aqui um sujeito político - principalmente tratando-se do Brasil, e mais particularmente, desses operários da Nova Lima na década de 1930 e 1940 - que transita incessantemente entre duas dimensões, a princípio distintas: entre a autonomia e a heteronomia. Nessa perspectiva, o sujeito deve ser pensado dentro do mundo e em relação com os outros, como um ser que cria, mas que também reproduz; e que nessa reprodução, sempre pode acrescentar algo singular. Ele pode jogar com os mecanismos de controle e disciplina, (re)apropriar-se deles e usá-los do seu jeito. Assim, podemos imaginar que é possível a convivência entre as duas dimensões. Esse sujeito é autônomo e heterônomo.

A palavra autônomo vem do grego: autos (eu mesmo, si mesmo) e nomos (lei, norma, regra). Aquele que tem o poder de estabelecer para si mesmo a regra, a norma, a lei, é autônomo e goza de autonomia, ou liberdade. Autonomia significa autodeterminação. Até que ponto esse sujeito político, esse operário é autônomo? Se ele cria estratégias, táticas, "maneiras de fazer" que alteram o cotidiano, até certo ponto podemos dizer que ele é alguém que tem o poder para criar suas próprias regras de sobrevivência, em relação ao outro. Porém, apesar de alguns sujeitos políticos conseguirem ser "livres", definindo o que desejam, independentemente de uma estrutura coletiva totalizante, ${ }^{35}$ não se pode negar que, muitas vezes, perde-se a capacidade racional para a autonomia. Os sujeitos passam a ser heterônomos. Heterônomo vem do grego: hetero (outro) e nomos; receber do outro a norma, a regra ou a lei. Essa talvez seja a grande dificuldade para a compreensão do sujeito político no Brasil e, no caso estudado, de compreender o imaginário operário da mina de Morro Velho, durante o governo de Vargas. Já está claro, todavia, que quando se pensa em sujeito político não se está necessariamente referindo-se a um partido, a uma classe, a um sindicato, ou mesmo ao Estado. A referência é a todos os homens que agem no socialhistórico; àqueles que, no dia a dia, vivem e praticam açóes. Àqueles que, tendo objetivos a alcançar, fazem escolhas e tomam decisões no espaço público da palavra e da ação. Ou seja, os brasileiros, os operários da mina de Morro Velho.

Até que ponto, no Brasil, fica-se entre a autonomia e a "servidão voluntária"? Ao se observar o operário que trabalhou na mina de Morro Velho, no período do getulismo, essa questão fica ainda mais complexa. As normas impostas ao trabalho dos mineiros apontam para um heteronomia social, ou seja, o completo controle do trabalho, dos sindicatos, do sistema previdenciário e da justiça trabalhista, o que se resumirá num conjunto de leis que ficou conhecido como CLT. Essas leis tiveram um papel importante na elaboração dessa memória/trajetória que constrói a figura de Getúlio Vargas como um mito, o estadista perfeito. A representação de Getúlio Vargas, gravada na memória do entrevistado, expressa a força do imaginário que foi criado durante o Estado Novo. 
As marcas impressas na memória social resultaram de uma intervenção direta no cotidiano operário, associada a um discurso que unia o governante à nação. $\mathrm{O}$ discurso de determinados sujeitos políticos, operários da mina, tendia, em parte, a reproduzir o discurso difundido e é nesse momento que a heteronomia encontra suas condições, para além do inconsciente individual e da relação intersubjetiva que aí aparece no mundo social.

A autonomia, em uma sociedade de heteronomia social, mesmo para os indivíduos para quem a autonomia possui um sentido, só pode permanecer truncada, porque encontra nas condições materiais e nos outros indivíduos, obstáculos renovados no momento em que tem de se encarnar em ação, desenvolver-se e existir socialmente; ela só pode manifestar-se, em sua vida efetiva, em interstícios dispostos pelo acaso e pela astúcia, em quotas sempre pequenas.

Talvez somente nessas pequenas quotas, somente nesses interstícios dispostos através dessas "astúcias", "táticas" e "estratégias" do cotidiano, o operário possa se tornar sujeito político, indivíduo autônomo, ser criativo, ou seja, quando emergem as possibilidades de transgressão. Ao que tudo indica, tratando-se de Brasil e do mundo moderno, o cotidiano de luta e resistência das mais diversas categorias de trabalhadores cede à força do discurso do Outro, do discurso oficial.

No entanto, voltemos à afirmação de Eugene Enriquez, com a qual iniciamos esta reflexão: "o sujeito é um ser criativo". Nesse sentido, acredito que, face à hegemonia dos discursos produzidos pelos órgãos oficiais do Estado e pela empresa inglesa (Saint John Del Rey Mining Company), aos operários de Morro Velho restava algum território, ainda que minúsculo, constituído por microcosmos de resistência à construção de representações e práticas de combate à dominação corporativa. Mesmo com todos os mecanismos de controle da palavra, ainda pode-se encontrar, nas práticas cotidianas, "maneiras de fazer"; práticas cotidianas, que se constituem em autonomias, em antidisciplinas, ou mesmo em criação de formas libertárias. No caso da experiência operária em Morro Velho, isso se coloca de maneira tão subliminar - na medida em que se refere a operários que não participaram das lutas sindicais do período - que parece ficar mais ao nível do inconsciente do que ao nível de uma consciência do sujeito. Essas microrresistências, ou mesmo criaçôes dos sujeitos políticos, parecem asfixiadas, perante a microfísica do poder implementada pelos ingleses, por seus "patrões de mina" e, pensando em termos mais gerais, macrofísicos, perante o próprio ideário getulista, com sua ideologia do homem novo, trabalhador nacional que deveria ser dócil e útil para a construção de uma nova nação.

Qual é, então, a possibilidade de se pensar o sujeito político, na contemporaneidade, no momento em que se constata a própria crise dos direitos dos cidadãos? Aliás, como é possível pensar em sujeitos políticos, no momento em que palavras como "ética", "cidadania" e "direito" começam a cair em desuso frente à avalanche promovida pela globalização?

A indústria cultural, através dos meios de comunicação mais difundidos, tenta normatizar a sociedade - como o rádio, sob controle do Estado varguista, tentou normatizar o operariado despolitizado isto é, transformar os sujeitos políticos, até então diferenciados, em massa igualada na exclusão. A supervalorização do econômico em relação ao político, social e cultural, faz com que todos se curvem, sem muito questionar, à realidade da "globalização". Talvez estejamos num momento em que se faz necessária a releitura de clássicos das ideias políticas, como Etienne de La Boétie, que examinou a questão da obediência em relação ao Estado, já em 1548, em seu Discurso sobre a servidão voluntária: poucos trabalham demais e muitos estão excluídos do processo produtivo; os que estão trabalhando mais aceitam essa condição e os que estão excluídos estão, em sua maioria, desorganizados e respondem com violência. Se somos heterônomos é porque, de certa forma, reconhecemos o Outro e aceitamos sua regra, sua norma. Talvez o homem só se torne sujeito político quando recuperar sua liberdade. De acordo com La Boétie:

Como é possível que tantos homens, tantas cidades, tantas nações suportem algumas vezes um único tirano, que apenas tem o poder que eles lhe atribuem, que não tem possibilidade de causar-lhes dano, ao qual (se quisessem) poderiam resistir, do qual não poderiam sofrer nenhum mal, se não preferissem tudo sofrer dele 
em vez de contradizê-lo? Coisa verdadeiramente surpreendente (e, contudo, tão comum, que antes temos de lamentá-la do que nos espantar com ela)! Ver milhôes e milhôes de homens miseravelmente subjugados e submetidos, de cabeça baixa, a um jugo deplorável; e não porque sejam obrigados a isso graças a uma força irresistível, mas porque são fascinados e, por assim dizer, enfeitiçados pelo único nome de um, que não deveriam temer, já que não é único, nem adorar, já que é - diante deles todos - desumano e cruel” (...) Disponham-se (...) a não servir e vocês serão livres. Não quero que vocês o combatam, nem que o derrubem, mas somente que não o sustentem; e verão que, tal como um grande colosso do qual se retira a base, ele tombará, por seu próprio peso e se quebrará. ${ }^{36}$

Por que cada homem aceita ser comandado? Por que há uma tendência à superação da autonomia pela heteronomia?

Termino essa breve reflexão, oriunda da análise do cotidiano operário em Nova Lima na Era Vargas, citando as palavras de Hannah Arendt, uma vez que elas nos possibilitam refletir em meio a esta quase impossibilidade de pensar sujeitos políticos no Brasil:

Não é preciso dizer que isto não significa que o homem moderno tenha perdido suas capacidades ou esteja a ponto de perdê-las. Digam o que disserem a sociologia, a psicologia e a antropologia acerca do "animal social", os homens persistem em fabricar, fazer e construir, embora estas faculdades se limitem cada vez mais aos talentos do artista, de sorte que as respectivas experiências de mundialidade escapam cada vez mais à experiência humana comum. [Nas palavras de Catão: Numquam se plus agere quam nibil cum ageret, numquam memis solum esse quam cum solus esset. Nunca ele está mais ativo do que quando nada faz, nunca está menos só que quando a sós consigo mesmo]. ${ }^{37}$

Quem sabe, em meio à "passividade" desse social-histórico coletivo anônimo, possa passear o sujeito político, agindo em seu silêncio, autônomo, "criador da história” em devir?

\section{Notas}

${ }^{1}$ DARNTON, Robert. O grande massacre dos gatos e outros episódios da história cultural francesa. Rio de Janeiro, Graal, 1986.

${ }^{2}$ Pronunciamento de Lourival Fontes, então Diretor Geral do DIP, a 18 de abril de 1942, na solenidade de instalação dos novos estúdios da Rádio Nacional. Apud SAROLDI, Luiz Carlos e MOREIRA, Sonia Virginia. Rádio Nacional. O Brasil em sintonia. Rio de Janeiro: Zahar, 2005.

${ }^{3}$ FERREIRA, Jorge. Trabalhadores do Brasil. O imaginário popular. Rio de Janeiro: Fundação Getúlio Vargas, 1997, p. 49.

${ }^{4}$ RESENDE, Maria Efigênia Lage de. O velho novo discurso conservador. Revista Brasileira de História, Rio de Janeiro, 1991, p. 36. Grifo nosso.

${ }^{5}$ Discurso de Getúlio Vargas, 1942, publicado no jornal Minas Geraes, p. 4.

${ }^{6}$ Apresentado pelo jornal Minas Geraes, de 21 de abril de 1942, p. 5 e 6.

${ }^{7}$ WISNIK, José Miguel. Algumas questões de música e política no Brasil. In: BOSI, Alfredo (Org.). Cultura Brasileira. Temas e Situaçôes. São Paulo: Ática, 1987. p. 114-123.

${ }^{8}$ FERREIRA. Jorge. Op. cit., p. 88.

${ }^{9}$ Entrevista de história de vida com o Sr. Waldir dos Santos realizada pela autora. Belo Horizonte, maio de 1995.

${ }^{10} \mathrm{Idem}$.

${ }^{11}$ Idem.

${ }^{12}$ Idem.

${ }^{13}$ Idem.

${ }^{14}$ CERTEAU, Michel de. A invenção do cotidiano. Petrópolis: Vozes, 1994. p. 47.

${ }^{15}$ Idem, ibidem, 1994, p. 85.

${ }^{16}$ CANCLINI, Néstor García. Culturas populares no capitalismo. Rio de Janeiro: Brasiliense, 1981. p. 129.

${ }^{17}$ Cf. OZOUF, Mona. A festa sob a Revolução Francesa. In: LE GOFF, Jacques; NORA, Pierre. História: Novos Objetos. Rio de Janeiro: Francisco Alves, 1989. p. 216-232.

${ }^{18}$ DAVIS, Natalie Zemon. Culturas do povo. Rio de Janeiro: Paz \& Terra, 1990. p. 87.

${ }^{19}$ Entrevista com o Sr. Waldir dos Santos realizada pela autora. Belo Horizonte, maio de 1995. 
${ }^{20}$ CERTEAU, Michel De; GIARD, Luce; MAYOL, Pierre. A invenção do cotidiano. 2. Morar, cozinhar. Petrópolis: Vozes, 1996.

${ }^{21}$ Idem, ibidem, p. 57.

${ }^{22}$ Ibidem, ibidem, p. 135.

${ }^{23}$ Idem, ibidem, p. 143.

${ }^{24}$ Cf. verbete "Cerveja e Bebedeira” em CHEVALIER, J.; GHEERBRANT, A. Dicionário de Símbolos. Rio de Janeiro: José Olympio, 1990.

${ }^{25}$ Entrevista com o Sr. Waldir dos Santos realizada pela autora. Belo Horizonte, maio de 1995.

${ }^{26}$ Idem.

${ }^{27}$ Entrevista com operário anônimo realizada por GROSSI, Yonne. A extração do homem. Petrópolis: Vozes, 1980. p. 72.

${ }^{28}$ GROSSI, Yonne. A extração do homem. Petrópolis, Rio de Janeiro: Vozes, 1980. p. 80.

${ }^{29}$ Essa análise parece se aproximar dos estudos sobre a carnavalização realizados por Michael Bakhtin.

${ }^{30}$ BACKTIN, Michael. Cultura Popular na Idade Média e no Renascimento. O contexto de François Rabelais. São Paulo: HUCITEC, EdUNB, 1987.

${ }^{31}$ BACKTIN, Michael. Op. cit., 1987.

${ }^{32}$ Idem.

${ }^{33}$ Entrevista com o Sr. Waldir dos Santos realizada pela autora. Belo Horizonte, maio de 1995.

${ }^{34}$ ENRIQUEZ, Eugene. Da horda ao Estado. Rio de Janeiro: Zahar, 1990.

${ }^{35}$ Como postulavam estruturalistas, como Louis Althusser e seus aparelhos ideológicos do Estado. Cf. Althusser, L. P. Aparelhos ideológicos de Estado. 7 ed. Rio de Janeiro: Graal, 1998. Nota do Editor.

${ }^{36}$ LA BOETIE, Etienne de. Apud CHATELET, François et al. História das Ideias Politicas. Rio de Janeiro: Zahar, 1985. p. 384.

${ }^{37}$ ARENDT, Hannah. A condição humana. Rio de Janeiro: Forense Universitária, 1983. p. 338.

\section{Referências}

\section{Fontes impressas}

Folha de Minas, Belo Horizonte, 12 de maio de 1936, p. 12. Manchete: "Acusados de Extremistas".

Minas Geraes, Belo Horizonte, 3 de setembro de 1936. Manchete: "Inaugura-se hoje a Rádio Inconfidência".

Minas Geraes, Belo Horizonte, 4 de setembro de 1936. Manchete: "A inauguração da Rádio Inconfidência”.

Minas Geraes, Belo Horizonte, 2 de maio de 1940. Manchete: "As comemorações do Dia do Trabalho em Belo Horizonte".

Minas Geraes, Belo Horizonte, 3 de setembro de 1940. Manchete: "Rádio. O aniversário da Rádio Inconfidência". Minas Geraes, Belo Horizonte, 21 de abril de 1942. Manchete: "Presidente Getúlio Vargas. A saudação do desembargador Mário Matos, pelo microfone da Rádio Inconfidência".

Minas Geraes, Belo Horizonte, 2 de maio de 1942. Manchete: "Produzir, produzir sem desfalecimentos, produzir cada vez mais".

\section{Fontes orais}

Entrevista com o Sr. Waldir dos Santos realizada pela autora. Belo Horizonte, maio de 1995.

\section{Referencias bibliográficas}

ARENDT, Hannah. A condição humana. Rio de Janeiro: Forense-universitária, 1983.

BACKTIN, Michael. Cultura Popular na Idade Média e no Renascimento. O contexto de François Rabelais. São Paulo: HUCITEC, EdUNB, 1987.

BOSI, Alfredo (Org.). Cultura Brasileira. Temas e Situações. São Paulo: Ática, 1987.

CANCLINI, Néstor García. Culturas populares no capitalismo. Rio de Janeiro: Brasiliense, 1981.

CERTEAU, Michel De; GIARD, Luce; MAYOL, Pierre. A invenção do cotidiano. 2. Morar, cozinhar. Petrópolis: Vozes, 1996. 
CHATELET, François et al. História das Ideias Politicas. Rio de Janeiro: Zahar, 1985.

CHEVALIER, J.; GHEERBRANT, A. Dicionário de Símbolos. Rio de Janeiro: José Olympio, 1990.

DARNTON, Robert. O grande massacre dos gatos e outros episódios da história cultural francesa. Rio de Janeiro, Graal, 1986.

DAVIS, Natalie Zemon. Culturas do povo. Sociedade e cultura no início da França moderna. Rio de Janeiro: Paz e Terra, 1990.

ENRIQUEZ, Eugene. Da horda ao Estado. Rio de Janeiro: Zahar, 1990.

FERREIRA, Jorge. Trabalhadores do Brasil. O imaginário popular. Rio de Janeiro: Fundação Getúlio Vargas, 1997.

GROSSI, Yonne. A extração do homem. Petrópolis, Rio de Janeiro: Vozes, 1980.

OZOUF, Mona. A festa sob a Revolução Francesa. In: LE GOFF, Jacques; NORA, Pierre. História: Novos Objetos. Rio de Janeiro: Francisco Alves, 1989.

RESENDE, Maria Efigênia Lage de. O velho novo discurso conservador. Revista Brasileira de História, Rio de Janeiro, 1991.

SAROLDI, Luiz Carlos; MOREIRA, Sonia Virginia. Rádio Nacional. O Brasil em sintonia. Rio de Janeiro: Zahar, 2005.

THOMPSON, E. P. Costumes em comum. Estudos sobre a cultura popular tradicional. São Paulo: Companhia das Letras, 1998.

WISNIK, José Miguel. Algumas questões de música e política no Brasil. In: BOSI, Alfredo (Org.). Cultura Brasileira. Temas e Situações. São Paulo: Ática, 1987.

\section{RESUMO}

O artigo pretende analisar algumas questôes fundamentais para a compreensão da vida cotidiana dos trabalhadores da mina de Morro Velho (Nova Lima, Minas Gerais), nas décadas de 1930 e 1940 (primeira fase do governo de Getúlio Vargas), destacando as antidisciplinas que esses trabalhadores foram construindo em seu cotidiano. O exame das diferentes formas de recepção às ideias divulgadas pelo Estado Novo permite identificar certas práticas presentes nesse meio operário: pequenas resistências face ao "colonizador" inglês; manifestaçôes de insubmissão às ideologias presentes no Estado varguista, em seu periodo autoritário.

Palavras-chave: trabalhadores do Brasil; Getúlio Vargas; cultura popular; ideias autoritárias; Minas Gerais.

\section{ABSTRACT}

This article analyzes some fundamental questions for understanding the daily life of Morro Velho (Nova Lima, Minas Gerais) mineworkers in the 1930s and 1940s (first phase of Getulio Vargas government), highlighting the anti-disciplines that these workers were constructing in their daily lives. The examination of different forms of reception to the ideas disseminated by the Estado Novo identifies certain practices present in this labor class: small resistances against English "colonizer" boss; expressions of insubordination to the ideologies present in Vargas State, in its authoritarian period. Keywords: Brazilian Workers; Getulio Vargas; popular culture; authoritarian ideas; Minas Gerais. 